talenta

\title{
SURVIVAL ANALYSIS OF NASOPHARYNGEAL CARCINOMA IN HASAN SADIKIN HOSPITAL
}

\author{
Riska Adriana ${ }^{1}$, Yussy Afriani Dewi ${ }^{2}$, Dindy Samiadi ${ }^{2}$ Edo Wira Candra ${ }^{3 *}$ \\ ${ }^{1}$ Hermina Arcamanik Hospital, Faculty of Medicine, Padjadjaran University, Bandung, Jawa Barat, Indonesia \\ ${ }^{2}$ Department of Otorhinolaryngology Head and Neck Surgery, Faculty of Medicine, Padjadjaran University, Bandung, Jawa Barat, Indonesia \\ ${ }^{3}$ EMC Sentul City Hospital, Faculty of Medicine, Padjadjaran University, Bandung, Jawa Barat, Indonesia
}

\section{Abstract}

Introduction: Nasopharyngeal carcinoma (NPC) is the fifth in range of malignancies in Indonesia and has high morbidity and mortality. A survival rate is a statistical index that summarizes the probable frequency of specific outcomes for a group of patients at a particular point in time. The survival of patients with nasopharyngeal carcinoma is influenced by several factors, such as the patient and tumor.

Objective: The objective of this research is to determine survival analysis and factors that influence nasopharyngeal carcinoma which recorded at Hasan Sadikin Hospital.

Methods: It is an analytic observational study. Data were analyzed with survival analysis using the Cox Regression test. Result: The subjects were 215 patients who were diagnosed NPC in first time at Hasan Sadikin Hospital from January 2006 until December 2009. There was a significant correlation between age, staging, histopathologic type and therapy with the survival $(\mathrm{P}=0.0001),(\mathrm{P}=0.026),(\mathrm{P}=0.0001),(\mathrm{P}=0.024),(\mathrm{P}=0.003)$; but no significant correlation between gender with the survival. Based on Cox proportional hazard, the male patients in over fifty years old have a risk of the death 7.724 and 1.113 times. The patients with nasopharyngeal carcinoma type have a risk of the death 2.381 times. The patients with stage IVC have a risk of the death 3183.9 times. The patients who underwent chemoradiation have a risk of the death 2.761 times.

Conclusion: The survival of patients with nasopharyngeal carcinoma is most influenced by prognostic factors such as age and therapy.
\end{abstract}

\section{Article Info}

Keywords:

Nasopharyngeal Carcinoma, Prognostic Factors, Survival

\section{*Corresponding author:}

Address: SMF. THT-KL FK Universitas Padjajaran, RS. Hasan Sadikin, Jl. Pasteur No. 38, Pasteur, Sukajadi, Kota Bandung, Jawa Barat 40161, Indonesia

e-mail: dr.edo.candra@gmail.com

\section{INTRODUCTION}

Nasopharyngeal carcinoma is a malignant tumor originating from the epithelium nasopharynx with the most common predilection in the Rosenmuller fossa. Nasopharyngeal carcinoma occurs due to interactions between genetic factors, Epstein Barr virus infection (EBV), environmental factors such as exposure to carcinogenic substances, smoke, and foods which contain nitrosamines such as salted fish [1].

Nasopharyngeal carcinoma ranks $23^{\text {rd }}$ of all malignancies in the world, the fifth of all malignancies in Indonesia, and is ranked first in head and neck malignancies division. The incidence of NPC in Indonesia reached 4.7 per 100,000 population per year, the highest in the decade 4-5 with a comparison between men and women, 2-3:1. Prevalence at ORL-HNS Department in Dr. Hasan Sadikin Bandung Hospital during 2006-2010 period is $41.7 \%$ [1-3]

Nasopharyngeal carcinoma is hard to diagnose early because of its location A patient often does not immediately come for treatment. Symptoms of NPC associated with the location of the primary tumor, infiltration of the tumor into the surrounding structure of nasopharynx, or lymph node metastasis. Mass in the nasopharynx can cause nasal symptoms such as nasal congestion and runny nose. Tumor ulceration will cause epistaxis. Ear symptom arises from expansion of the mass around the eustachian tube which causes fluid arises in the middle ear, unilateral conductive deafness, otalgia, and tinnitus. Serous otitis media was found in $41 \%$ of 237 patients diagnosed with NPC. Tumor growth can extend to the skull cavity through the lacerum foramen which affects the anterior group and posterior group which results in cranial nerve abnormalities [1]. Tumor metastasis to neck lymph nodes can occur unilateral or bilateral. Enlargement of the neck often occur $(60 \%-97.5 \%)$ and is the main reason people come to doctor The retrospective study by Aribas et al. in 2008 shows that the lymphadenopathy found in $76 \%$ patients, nasal symptoms in $73 \%$, ear symptoms in $62 \%$ patients, and cranial nerve disorders in $20 \%$ patients $[1,4,5]$.

Nasopharyngeal carcinoma has high morbidity and mortality despite the modality of treatment [5]. Data in the United Kingdom in 2014, shows that the five-year survival rate in stage I, stage II, stage III, and stage IV in chronological order are $80 \%, 65 \%, 60 \%$, and $50 \%$. Whereas data statistics in
America in 2014, shows that the five-year survival rate in stage I, stage II, stage III, and stage IV in chronological order is $72 \%, 64 \%, 62 \%$, and $38 \%$ [6].

A survival rate of NPC depends on several factors, such as the aggressiveness of tumor cells based on tumor expansion, expansion to collie lymph nodes, and distant metastasis, as well as patient characteristics, age, race, and gender. Other factors also influence the prognosis, such as NPC histopathology classification based on the World Health Organization (WHO), and therapeutic intervention in NPC patients [4]. A study by Lee et al. in Taiwan in 2011 found that factors affecting the survival rate of NPC are socioeconomic, geographical location, hospital facilities, and clinical stages of the NPC [7]. El-Sherbieny in Kuala Lumpur showed that NPC stage and histopathological features could be affecting survival rate. Nonkeratinized squamous cell carcinoma (SCC) and undifferentiated carcinoma had a higher survival rate compared with keratinized squamous cell carcinoma [8].

A study in Brazil in 2003 showed that patient's age, clinical stage, histopathology, and therapy could affect the survival rate. Despite that nasopharyngeal carcinoma is a radiosensitive tumor, at the advanced stage the response is decreasing. A study in Brazil showed that patients with stage III NPC in Brazil had a five-year survival rate of $28 \%$ and stage IV around $35 \%$ [9]. The survival rate is the percentage of individuals who survive certain diseases, in this case, is NPC, for a specified amount of time [10]. Medical studies often use the overall survival in assessing the effectiveness of the therapy that can affect prognosis and survival rate [11]. Patient condition and tumor factors influence the survival rate of the NPC. The survival rate is analyzed with a specific design using survival analysis. Survival analysis is described as a set of statistical procedures using an analytical method to analyze variables, which outcome is time until the occurrence of specific events, such as death, disease recurrence, or recovery. Time can be measured by year, month, day, hour, or a minute from the observation until the events $[12,13]$.Survival rate and factors that affect patients with nasopharyngeal carcinoma at Hasan Sadikin Hospital Bandung never been studied. Based on these considerations, this research was conducted. 


\section{MATERIAL AND METHODS}

This study is an analytic observational study with a special design of survival analysis. Data were collected retrospectively from medical records. The subjects of the study were patients diagnosed with NPC in the period January 2006 until December 200 in the ORL-HNS Department at the Dr. Hasan Sadikin Bandung Hospital and met the inclusion criteria.

Data were collected from medical records, such as age, sex, race, education, occupation, socioeconomics, clinical stage, histopathology, therapy, and patient response. Then the patient or family is contacted by the researcher to find out whether the patient is alive or dead. Data were analyzed with survival analysis using the Cox Regression test.

\section{RESULT}

The number of sample data obtained is 215 which are included in the inclusion and exclusion criteria.

Table 1. Life Table of NPC

\begin{tabular}{lccc}
\hline \multirow{2}{*}{ Time (years) } & $\begin{array}{c}\text { Number of death } \\
\text { (\%) }\end{array}$ & Survival Rate (\%) & SE \\
\hline 1 & 11 & 86.9 & 0.02 \\
2 & 49 & 52.9 & 0.02 \\
3 & 72 & 3.0 & 0.02 \\
4 & 84 & 33.2 & 0.02 \\
5 & 90 & 30.9 & 0.02 \\
\hline note: & & & \\
SE: standard error & & &
\end{tabular}

Table 1 is a cumulative life table of NPC patients in the first to the fifth year. In the first year, subjects who died is $11 \%$ and those who survive is $86.9 \%$. In the second year, the subject who died became $49 \%$ and those who survive is $52.9 \%$. In the third year, subjects who died increased by $72 \%$ and those who survive decreased to $38.9 \%$. In the fourth year subjects who died became $84 \%$ and those who survive were $33.2 \%$. In the fifth year, subjects who died is $90 \%$ and those who survive is $30.9 \%$.

Table 2. Survival Rate

\begin{tabular}{|c|c|c|c|}
\hline Prognostic Factors & $\begin{array}{c}\text { Total } \\
(\mathrm{n}=\mathbf{2 1 5})\end{array}$ & $\begin{array}{c}\text { Percentage } \\
(\%)\end{array}$ & $\begin{array}{c}\text { Survival Rate } \\
(\%)\end{array}$ \\
\hline \multicolumn{4}{|l|}{ Age } \\
\hline$<20$ years & 5.0 & 2.3 & 76.1 \\
\hline $20-29$ years & 14.0 & 6.5 & 9.2 \\
\hline $30-39$ years & 34.0 & 15.8 & 11.8 \\
\hline $40-49$ years & 77.0 & 35.9 & 2.9 \\
\hline$>50$ years & 85.0 & 39.5 & 0 \\
\hline \multicolumn{4}{|l|}{ Sex } \\
\hline Man & 148.0 & 68.8 & 32.3 \\
\hline Woman & 67.0 & 31.2 & 67.7 \\
\hline \multicolumn{4}{|l|}{ Race } \\
\hline Deutro Malay & 192.0 & 89.3 & 89.2 \\
\hline Malay & 12.0 & 5.6 & 4.6 \\
\hline Mongoloid & 11.0 & 5.1 & 6.2 \\
\hline \multicolumn{4}{|l|}{ Occupation } \\
\hline Government Employee & 20.0 & 9.3 & 4.6 \\
\hline Private Employee & 108.0 & 50.2 & 2.9 \\
\hline Labor/maid & 82.0 & 38.2 & 28.7 \\
\hline Student & 5.0 & 2.3 & 53.8 \\
\hline \multicolumn{4}{|l|}{ Level of Education } \\
\hline Primary school & 100.0 & 46.5 & 15.4 \\
\hline Junior high school & 28.0 & 13 & 24.6 \\
\hline High school & 45.0 & 21 & 29.2 \\
\hline College & 42.0 & 19.5 & 30.8 \\
\hline \multicolumn{4}{|l|}{ Socioeconomics } \\
\hline Very low income & 30.0 & 14.0 & 9.2 \\
\hline Low Income & 79.0 & 36.8 & 29.2 \\
\hline Medium Income & 52.0 & 24.2 & 27.7 \\
\hline Standard Income & 54.0 & 25.0 & 33.8 \\
\hline \multicolumn{4}{|l|}{ Histopathology } \\
\hline WHO Type I & 10.0 & 4.6 & 0 \\
\hline WHO Type II & 22.0 & 10.2 & 6.2 \\
\hline WHO Type III & 183.0 & 85.2 & 93.8 \\
\hline \multicolumn{4}{|l|}{ Clinical Stage } \\
\hline Stage I & 1.0 & 0.5 & 44.6 \\
\hline Stage II & 25.0 & 11.6 & 24.6 \\
\hline Stage III & 58.0 .0 & 27.0 & 15.4 \\
\hline Stage IVA & 41.0 & 19.1 & 13.8 \\
\hline Stage IVB & 84.0 & 39.0 & 1.5 \\
\hline Stage IVC & 6.0 & 2,8 & 0 \\
\hline \multicolumn{4}{|l|}{ Therapy } \\
\hline Radiotherapy & 25.0 & 11.6 & 23.1 \\
\hline Chemoradiation & 190.0 & 88.4 & 76.9 \\
\hline \multicolumn{4}{|l|}{ Response } \\
\hline Complete & 213.0 & 99.0 & 100.0 \\
\hline Residing & 1.0 & 0.5 & 0 \\
\hline Recurrent & 1.0 & 0.5 & 0 \\
\hline
\end{tabular}

Based on age distribution, NPC patient was dominant in the age group for more than 50 years ( 89 people). The survival rate for the age group less than 20 years, $20-29$ years, $30-39$ years, $40-49$ years and more than 50 years, respectively is $76.1 \% ; 9.2 \% ; 11.8 \% ; 2.9 \% ; 0 \%$. Men are more common than women ( $68.8 \%$ vs. $31.2 \%$ ). The overall survival rate for men and women is $32.3 \%$ and $67.7 \%$. According to race distribution, Deutro Malay is more common than Malay and Mongoloid, with the survival rate is $89.2 ; 4,6 \%$; and $6.2 \%$.

Based on occupation, most NPC patients were private employees (108 people $/ 50.2 \%$ ). The overall survival rate for government employees, private employees, labor/ maid, and students are $4.6 \% ; 2.9 \% ; 28.7 \% ; 53.8 \%$. Most NPC patients had a low level of education, equivalent to Primary School (46.5\%). The survival rate for elementary school-graduates, Junior High School graduates, High School Graduates, and University graduates are $24.6 \% ; 15.4 \% ; 29.2 \% ; 30.8 \%$. Low income patients were common $(36.8 \%)$ with survival rate for very low income, low income patient, middle income, and standard income patients are $9.2 \% ; 29.2 \% ; 27.7 \% ; 33.8 \%$.

The most common carcinoma were type 3 WHO or undifferentiated carcinoma $(85.2 \%)$, with survival rate for type 1,2 , and 3 are each $0 \% ; 6.2 \%$; $93.8 \%$. Based on the clinical stage, the most patient was diagnosed in stage IV (39\%). Survival rate for stage I, II, III, IVA, IVB, and IVC are $44.6 \% ; 24.6 \%$; $15.4 \% ; 13.8 \% ; 1.5 \%$; and $0 \%$. Combination therapy of radiotherapy and chemotherapy is the most common management (88.4\%). The overall survival rate for radiotherapy and chemotherapy are $23.1 \%$ and $76.9 \%$. Most NPC patients had a complete response (99\%) with a $100 \%$ survival rate.

The results of the statistical analysis for the hazard ratio is shown in table 3. Patient's age, level of education, histopathology of the tumor, clinical stage, and therapy were significant (P-value $<0.05$ ). Age above 50 years have a poorer survival rate among another age group, with the hazard ratio 7.724 meaning that patients older than 50 years old were 7.724 times more likely to die. Based on the histopathology, the data showed that WHO type 1 nasopharyngeal carcinoma had the most higher hazard ratio than type 2 or 3 . Based on the clinical stage of the tumor, we found that patient with the IV C clinical stage were 3183.926 times more likely to die. Patient undergoing radiotherapy had better survival than chemoradiation. Based on the hazard ratio, chemoradiation therapy had a value of 2.761 which indicates that at any time, death was more likely to happen than in patients undergoing radiotherapy.

Table 3. Bivariate Analysis of Hazard Ratios Based on Alive and Death Category

\begin{tabular}{|c|c|c|c|}
\hline \multirow{2}{*}{ Variable } & \multicolumn{2}{|c|}{ Hazard Ratio } & \multirow{2}{*}{ Pvalue } \\
\hline & B value & Exp. B & \\
\hline \multicolumn{4}{|l|}{ Age } \\
\hline$<20$ years & & & 0.0001 \\
\hline $20-29$ years & 0.692 & 1.998 & \\
\hline $30-39$ years & 0.834 & 2.303 & \\
\hline $40-49$ years & 1.511 & 4.529 & \\
\hline$>50$ years & 2.044 & 7.724 & \\
\hline \multicolumn{4}{|l|}{ Sex } \\
\hline Man & 0.107 & 1.113 & 0.545 \\
\hline Woman & & & \\
\hline \multicolumn{4}{|l|}{ Race } \\
\hline Deutro Malay & 0.161 & 1.174 & 0.701 \\
\hline Malay & 0.405 & 1.500 & \\
\hline \multicolumn{4}{|l|}{ Mongoloid } \\
\hline \multicolumn{4}{|l|}{ Occupation } \\
\hline Government employee & 1.949 & 7.020 & 0.160 \\
\hline Private Employee & 1.515 & 4.548 & \\
\hline Labor/maid & 1.531 & 4.622 & \\
\hline Student & & & \\
\hline \multicolumn{4}{|l|}{ Education } \\
\hline Primary School & 0.399 & 1.491 & 0.026 \\
\hline Junior High School & -0.062 & .940 & \\
\hline High School & -0.195 & .823 & \\
\hline \multicolumn{4}{|l|}{ College } \\
\hline \multicolumn{4}{|l|}{ Socioeconomics } \\
\hline Very low income & 0.290 & 1.336 & 0.688 \\
\hline Low income & 0.122 & 1.129 & \\
\hline Medium Income & 0.016 & 1.017 & \\
\hline \multirow{2}{*}{\multicolumn{4}{|c|}{$\begin{array}{l}\text { Standard Income } \\
\text { Histopathology }\end{array}$}} \\
\hline & & & \\
\hline WHO type I & 0.868 & 2.381 & 0.024 \\
\hline WHO type II & 0.261 & 1.298 & \\
\hline \multicolumn{4}{|l|}{ WHO type III } \\
\hline \multicolumn{4}{|l|}{ Clinical Stage } \\
\hline Stage I & & & 0.0001 \\
\hline Stage II & 6.231 & 508.216 & \\
\hline Stage III & 6.589 & 727.248 & \\
\hline Stage IVA & 7.302 & 1483.919 & \\
\hline Stage IVB & 7.781 & 2393.697 & \\
\hline Stage IVC & 8.066 & 3183.926 & \\
\hline \multicolumn{4}{|l|}{ Therapy } \\
\hline Radiotherapy & & & 0.003 \\
\hline Chemoradiation & 1.016 & 2.761 & \\
\hline \multicolumn{4}{|l|}{ Response } \\
\hline Recurrent & -2.517 & 0.081 & 0.111 \\
\hline Residing & 1.965 & 7.137 & \\
\hline Complete & & & \\
\hline
\end{tabular}


Table 4. Multivariate analysis between independent variables and survival rate

\begin{tabular}{lcccc}
\hline \multirow{2}{*}{ Variable } & \multirow{2}{*}{ Hazard Ratio } & \multicolumn{2}{c}{ CI 95\% } & \multirow{2}{*}{ P value } \\
\cline { 3 - 4 } & & Upper Level & Lower Level & \\
\hline$<20$ years old & & & & 0.000 \\
$20-29$ & 2.414 & 0.282 & 20.694 & 0.421 \\
$30-39$ & 2.587 & 0.340 & 19.688 & 0.359 \\
$40-59$ & 4.980 & 0.688 & 36.059 & 0.112 \\
$>50$ & 8.788 & 1.218 & 63.395 & 0.031 \\
Therapy & 2.850 & 1.448 & 5.610 & 0.002 \\
\hline
\end{tabular}

Multivariate analysis was done to assess the magnitude of the relationship between variables with a 5-years survival where the p-value is less than $0.05(\mathrm{P}<0.05)$. In the next step, multivariate analysis will see the effect of each variable by looking at the hazard ratio. Based on this analysis, variables that had the most influence on the survival rate of NPC patients based on the hazard ratios are the patient's age and therapy, with 95\% CI.

\section{DISCUSSION}

Table 2 explains the variable age of the dominant patient is the age group of more than 50 years, which is as many as 89 people. The same results were reported by Putri in Bandung regarding the characteristics of patients with nasopharyngeal carcinoma in the ORL-HNS Department of Padjadjaran University, Hassan Sadikin Central Hospital in the period 2006-2010 that had a higher incidence of NPC at the age of 50-59 years. Research conducted by Heng et al. Reported the highest prevalence of NPC at the age of 40-59 years [14]. All of these studies showed the first exposure to carcinogenic substances until the onset of cancer takes a long time [2, 3]. The most commonly histopathological type found is WHO type III, which is undifferentiated carcinoma as many as 183 people $(85.2 \%)$ compared to WHO types I and II. These results are in accordance with Adham et al., Who reported that WHO type III was found to be around $85 \%$ while WHO type II was found to be $2.3 \%$ [2]. The El-Sherbieny study et al. Reported that WHO type III was more dominant than WHO type II, each of which was 106 people $(67 \%)$ and 53 people $(33 \%)$. Research Xiao et al got the highest WHO type III results compared to WHO types I and II, each of which amounted to 185 people $(86.9 \%), 25$ people $(11.7 \%), 3$ people $(1.4 \%)$ [15]. All of these studies were due to WHO type III in Southeast Asia and in other countries with a high incidence of NPC, besides of that undifferentiated carcinoma have a strong correlation with EBV and found high p53 gene expression that correlated with high tumor cell proliferation $[2,16,17]$.

Most of the patients with NPC in this study were given combination therapy of radiotherapy and chemotherapy, namely 190 people $(88.4 \%)$, and from the overall therapy that received a complete response of 213 people $(99 \%)$. Aribas et al. study, reported that there were about 175 people with NPC treated by combination radiotherapy and chemotherapy compared to radiotherapy alone, who received a complete response are 217 people [4]. Al-Sarraf reported that treatment of NPC with a combination of radiotherapy and chemotherapy resulted in $89 \%$ complete responses. This is because NPC is chemosensitive and radiosensitive. Tumor cell Radiosensitivity depend on several factors, namely cell differentiation and cell proliferation cycles that are known to have a role in influencing the effects of radiation on cells in phases Gap 2 (G2) and mitosis (M) $[4,9,18]$. The success of chemotherapy depends on the size of the tumor and the percentage of tumor cells responsive to chemotherapy $[1,5,19]$.

Table 3 explains the relationship between age and survival using a statistical test known $\mathrm{P}$-value of $0.0001(\mathrm{P}$-value $<0.05)$. This shows that there is a statistically significant relationship between age category variables and survival, based on life and death groups. At the age above 50 years have worse survival compared to other age categories. The value of the hazard ratio is 7.724 shows that every time death is faster in the age category above 50 years. This result is similar to Burt et al. Study who reported that age was an independent variable that significantly affected survival, where the value of $\mathrm{P}<0.001$. Ou et al studied 2.436 NPC patients with results that at a younger age had a better survival statistically P-value $<0.0001$ [18]. All the results of the study were due to age associated with the carcinogenesis process which consists of several mechanisms namely the accumulation of cells within tissue in the process of carcinogenesis occurs at an advanced stage and changes in hemostasis, immune system and endocrine can occur. Old age can be accompanied by comorbidities such as diabetes, hypertension, myocardial infarction which can worsen the general condition so that it affects the therapy to be carried out and tends to worsen conditions due to therapy for example nephrotoxicity, myelosuppression, electrolyte disorders, diarrhea, nausea and vomiting [7, 15, 20].

Table 3 explains the relationship between education and survival using statistical tests. It is known that the $\mathrm{P}$-value is 0.026 ( $\mathrm{P}$-value $<0.05)$. This shows that there is a statistically significant relationship between education variables on survival based on life and death groups. Higher education has better survival. The highest hazard ratio in the elementary education category is 1.491 times which indicates that at any time the death is faster in the elementary education group. The same results as Putri's research showed that the highest level of education for NPC patients was 259 elementary school students $(52.5 \%)$ so that due to low levels of intellectuality the patients did not know the early symptoms of NPC, so there was a delay in treatment [3].

The association of histopathological type with survival using statistical tests is known to have a P-value of 0.024 ( $\mathrm{P}$-value $<0.05$ ). This shows that there is a statistically significant relationship between histopathological variables on survival based on life and death groups. WHO type I has the highest hazard ratio value of 2.381 which indicates that WHO type I every time of death is faster than WHO type III. The same study results of Thompson et al. that keratinized squamous cell carcinoma has a worse survival $(20 \%-40 \%)$ compared to undifferentiated carcinoma (65\%). Reddy et al. reported that WHO type I significantly affected the 5 years survival (P-value=0.001). Hsu et al. reported 78 cases of NPC with WHO type I had worse survival than WHO types II and III. (P-value<0.0000) [21]. This is due to keratinized squamous cell carcinoma has a large tendency in local growth of the tumor, is not closely related to EBV infection, and is less radiosensitive [1, 2].

In table 3 it can be seen the relationship between the stage of the disease with survival using a statistical test with a $\mathrm{p}$-value of $0.0001(\mathrm{P}$-value $<0.05)$. This shows that there is a statistically significant relationship between the stadium variables on survival based on life and death groups. In stage I, have better survival. These results are in accordance with Farius et al. study, reporting 5-years survival in stage I was better than stage II, III and IV, which was $100 \%$ [9]. Liu et al. get the results of stage I and II having a 3year survival better than stage III and IV. This is because the possibility of metastasis in patients with NPC with an early stage is very low [22]. Research Chua et al., Who reported stage I had a better 10-years survival of $98 \%$ [23]. Based on the value of the hazard ratio, stage IVC had the highest value of 3183.926 times where at any time death was faster in stage IVC. Clinical research according to Kong says the clinical stage of NPC is related to prognosis. People with NPC with stage IVC where the tumor has metastasized has a survival of less than $10 \%$ [24].

The therapy given has a relationship with survival through a statistical test with a $\mathrm{P}$-value of $0.003(\mathrm{P}$-value $<0.05)$. This shows that there is a statistically significant relationship between therapeutic variables on survival based on life and death groups. In NPC patients, radiotherapy has better survival than chemoradiation. Kong et al. Reported a 5-years survival of NPC patients with radiotherapy reaching 50\%-80\% [24]. Chua et al. Study reported 141 people in stages I and II had very good results, 10-years survival reached $98 \%$ [23]. Based on the hazard ratio combination between radiotherapy and chemotherapy have a value of 2,761 times which indicates that at any time death is faster than in patients with radiotherapy therapy. Therapy on NPC is given in order to reduce tumor progression. Therapy is also closely related to stage. Radiotherapy is a therapeutic modality for NPC at an early stage, while combination therapy for radiotherapy and chemotherapy is given at an advanced stage. The results of therapy will be bad if the primary tumor is large, infiltrative, ulcerative, extended to the intracranial, large neck tumor, and distant metastasis. So that it can be concluded that survival in patients with NPC with combination therapy of radiotherapy and chemotherapy will be worse than radiotherapy [1, 24, 25].

Based on the multivariate analysis in table 4 , it can be explained that the variables that most influence the survival of NPC patients based on P-values $<0.05$ and the order of strength of hazard ratios are age and therapy categories.

In this study there are limitations, that is data from the medical record have no shown comorbidities in NPC patients who can aggravate general conditions such as diabetes, hypertension, myocardial infarction. Another limitation is the absence of nutritional medical record data on NPC patients who can have an impact on increasing morbidity and mortality [26, 27].

\section{CONCLUSION}

The characteristics of NPC patients who are the subjects of the study are more commonly found in men and over 50 years of age. The most dominant Patients with NPC are Malay deutro race. Most types of work distribution are private employees. The highest level of education for NPC patients is an elementary school. The low-income socioeconomic group is the dominant variable. The most histopathological type is the WHO type III NPC. The most common therapy is a combination therapy of radiotherapy and chemotherapy. The survival of NPC patients is influenced by prognostic factors, namely age, sex, education, histopathology type, clinical stage, and therapy. 


\section{REFERENCE}

[1] Wei W, Chua D. Nasopharyngeal Cancer. Dalam Bailey BJ, Healey GB, Johnson JT, Rosen CA dkk, Penyunting. Head and Neck Surgery otolaryngology Philadelphia Lippincott Williams \& Wilkins. 187; 4: 97.

[2] Adham M, Kumiawan AN, Muhtadi AI, Roezin A, Hermani B, Gondhowiardjo S, EtAl. Nasopharyngeal Carcinoma in Indonesia: Epidemiology, Incidence, Signs, and Symptoms at Presentation. Chinese Joumal of Cancer. 2012;31(4):185.

[3] Putri E B. Karakteristik Penderita Karsinoma Nasofaring di Departemen Ilmu Kesehatan THT-KL FKUP/RSUP Dr. Hasan Sadikin Bandung Periode Tahun 2006-2010. Universitas Padjajaran. 2011

[4] Aribas B, Cetindag F, Ozdogan Z, Dizman A, Demir P, Unlu D. et al. Nasopharyngeal Carcinoma: Prognostic Factors and Treatment Features. Journal of The Egyptian Nat Cancer Inst. 2008; 20:230-6.

[5] Chong VF. Neoplasms of The Nasopharynx. Head and Neck Cancer Imaging: Springer; 2008: 143-62.

[6] Cheng SH, Jian JJ-M, Tsai SY, Yen KL, Chu N-M, Chan K-Y, Et Al. LongTerm Survival of Nasopharyngeal Carcinoma Following Concomitant Radiotherapy and Chemotherapy 1. International Journal of Radiation Oncology Biology Physics. 2000; 48(5):1323-30.

[7] Lee C-C, Huang T-T, Lee M-S, Su Y-C, Chou P, Hsiao S-H, EtAl. Survival Rate In Nasopharyngeal Carcinoma Improved By High Caseload Volume: A Nationwide Population-Based Study In Taiwan. Radiation Oncology. 2011;6(1):92.

[8] El-Sherbieny E, Rashwan H, Lubis SH, Choi VJ. Prognostic Factors In Patients With Nasopharyngeal Carcinoma Treated In Hospital Kuala Lumpur. Asian Pac J Cancer Prev. 2011; 12(7):1739-43.

[9] Farias TP, Dias FL, Lima RA, Kligerman J, De Sá GM, Barbosa MM, Et Al Prognostic Factors and Outcome for Nasopharyngeal Carcinoma. Archives of Otolaryngology-Head \& Neck Surgery. 2003; 129(7):794-9.

[10] Food and Drug Administration: Oncology Center of Excellence Guidance for Industry: Clinical Trial Endpoints for the Approval of Cancer Drugs and Biologics U.S. Department of Health and Human Services. 2007; 72.

[11] Compton CC. Cancer Survival Analysis. American Joint Committee on Cancer 2012;23-31.

[12] Gayatri D. Mengenal Analisis Ketahanan (Survival Analysis). Jurnal Keperawatan Indonesia. 2005;9(1).

[13] Survival Analysis. Research Methods-II Multivariate Analysis. Oxford Journal. 2015;128-35.

[14] Ching LJ. Prognostic Factors In Nasopharyngeal Cancer. Multidisciplinary Management. 2010;95-136.

[15] XiaoG,CaoY, QiuX, WangW, WangY. Influence of GenderandAge on The Survival of Patients with Nasopharyngeal Carcinoma. BMC Cancer. 2013; 13(1):226.

[16] Umar B, Ahmed R. Nasopharyngeal Carcinoma, An Analysis of Histological Subtypes and Their Association with EBV, A Study of 100 Cases of Pakistan Population. Asian Journal of Medical Sciences 2014 Oct-Dec;5(4):17.

[17] Nicholls J, Niedobitek G. Histopathological Diagnosis of Nasopharyngeal Carcinoma: Looking Beyond The Blue Book. Nasopharyngeal Carcinoma: Springer; 2013;10-22.

[18] Wee J.Concurrent Chemotherapy-Enhanced Radiation: Trials and Conclusions. Nasopharyngeal Cancer: Springer; 2010;167-81.

[19] Gourin CG, Forastiere AA. Chemoradiation. At Bailey BJ, Healey GB, Johnson JT, Rosen CA, Et Al Head and Neck Surgery-Otolaryngology 5th Edition. 2015;1692-93.

[20] Anisimov VN. The Relationship Between Aging and Carcinogenesis: ACritical Appraisal. Critical Reviews In Oncology/Hematology. 2003; 45(3):277-304.

[21] Dahlan S. Analisis Survival: Dasar-Dasar Teori dan Aplikasi Program Stata. Jakarta. Sagung Seto. 2009;1-50.

[22] Liu M-T, Hsieh C-Y, Chang T-H, Lin J-P, Huang C-C, Wang A-Y. Prognostic Factors Affecting The Outcome of Nasopharyngeal Carcinoma. Japanese Journal of Clinical Oncology. 2003; 33(10):501-8.

[23] Ove R, Allison RR, Lu JJ. Early Stage Nasopharyngeal Cancer: A Highly Curative Disease with Radiation Therapy. Nasopharyngeal Cancer: Springer; 2010;137-47.

[24] Kong F, Cai B-Z, Chen X-Z, Zhang J, Wang Y-M. Prognostic Factors for Survival of Patients with Nasopharyngeal Carcinoma Following Conventional Fractionation Radiotherapy. Experimental and Therapeutic Medicine. 2013;6(1):57-60.

[25] Kentjono W. Perkembangan Terkini Penatalaksanaan Karsinoma Nasofaring. Majalah Kedokteran Tropis Indonesia. 2003;14(2):1-39.

[26] Jager-Wittenaar H, Dijkstra P, Van Der Laan B, Vissink A, Van Oort R, Roodenburg J. Critical Weight Loss In Head and Neck Cancer Patients: Prevalence and Risk Factors at Time of Diagnosis. Clinical Otolaryngology. 2007;32(2):155.

[27] Surachman DP. Tinjauan Kehidupan Sosial Ekonomi Keluarga Pemulung di Desa Tapian Nauli Lingkungan IX Kelurahan Sunggal Kecamatan Medan Sunggal. Universitas Sumatera Utara. 2015;10-41 